Scientific Journal Warsaw University of Life Sciences - SGGW

Problems of World Agriculture volume 20 (XXXV), number 1, 2020: 15-24

DOI: 10.22630/PRS.2020.20.1.2

Bartlomiej Bajan $^{1}$, Aldona Mrówczyńska-Kamińska ${ }^{2}$

Poznań University of Life Sciences, Poland

\title{
Supply of Materials to the Agribusiness Sector of European Union Countries
}

\begin{abstract}
The purpose of this paper was to assess the prevailing relationships in the supply structure of the agribusiness sector in European Union countries over the years. The study focused on 25 European Union countries (Cyprus, Luxembourg and Malta were excluded) to address the changes in the supply structures of agriculture and food industries, the two major components of agribusiness. The study was of a dynamic nature. Although the study period was 2000-2014, this paper only presents the figures for the first and the last year, i.e. 2000 and 2014. The main focus was on drawing conclusions on the trends observed which proved to be relatively stable in the years covered. The input-output analysis was used by aggregating the sectors of the economy for a better transparency of the inference process. As shown by this study, EU countries at higher development levels witness a decline in the share of the chemical industry in the mix of goods and services supplied to agriculture. Conversely, less developed countries saw that ratio increase. Also, the share of goods supplied to agriculture from the fuel and energy sectors goes up in most EU countries. As regards the food industry, this study observed high shares of agriculture, services and self-supply in the supply structure of EU countries. This analysis extends the existing knowledge on the relationships in the structure of materials supplied to the agribusiness because in addition to agriculture itself (which was addressed by similar studies found in literature) it takes account of the food industry. Moreover, based on long-term observations, it endeavors to capture the prevailing relationships in several countries at a time.
\end{abstract}

Keywords: material supply, agribusiness, food industry, agriculture, European Union

JEL Classification: O13, Q00, Q13

\section{Introduction}

Agribusiness, also known as the food economy, agri-food complex or agri-food sector, is a subsystem of the national economy which has developed its own internal connections while being strongly integrated with other sectors. The pace of agribusiness development considerably depends on its internal structure and on the relations it has with other sectors (Mrówczyńska-Kamińska, Baer-Nawrocka, 2016). However, these conclusions largely depend on the definition used. The extensive nomenclature alone suggests that agribusiness can be understood in many ways.

The first definition was provided by Davis and Goldberg (1957), authors of the concept itself, who considered it to be "the total of all operations involved in the

\footnotetext{
${ }^{1}$ M.Sc., Department of Economics and Economic Policy in Agribusiness, Faculty of Economics and Social Sciences, Poznań University of Life Sciences, Wojska Polskiego 28, 60-637 Poznań, e-mail: bartlomiej.bajan@up.poznan.pl; https://orcid.org/0000-0003-1393-6580

2 Associate professor, Department of Economics and Economic Policy in Agribusiness, Faculty of Economics and Social Sciences, Poznań University of Life Sciences, Wojska Polskiego 28, 60-637 Poznań, e-mail: aldonam@up.poznan.pl; https://orcid.org/0000-0001-5439-7339
} 
manufacture and distribution of farm supplies; production operations on the farm; and the storage, processing, and distribution of farm commodities and items made from them" (Davis, Goldberg, 1957). However, they also found that different classifications could be used to facilitate the analysis, and adopted two different approaches themselves. In the initial concept, agribusiness was divided into three aggregates: farm supplies, agriculture, and processing and distribution of agricultural produce. Davis and Goldberg carried out an in-depth analysis of interdependencies and redefined the three aggregates to be used as a reference for research findings, namely: agriculture, food processing and fiber plant processing (at that time, these were believed to be the key components of agribusiness in the United States).

The relevant literature provides two main methods for estimating the size of agribusiness based on input-output tables. The first one uses the I/O figures to develop forecasts that go beyond the tables published in official statistics (Schluter et al., 1986). However, it is heavily affected by the unrealistic assumption that economic structures remain constant (Yan et al., 2011). That assumption was relaxed in the second method, proposed by Furtuoso et al. (1998), which enables estimating the size of agribusiness based directly on I/O tables. Furtuoso et al. (1998) used their own method to divide agribusiness into 4 aggregates: a) inputs to agriculture: this includes the part of all sectors that supply products to agriculture; b) agriculture; c) agriculture-based industries: these include industries the most related to agriculture in terms of demand for its products; and d) final distribution, which estimates the share of agribusiness products in value added of Transportation, Commerce and Service sectors. The above is consistent with the division of the food supply chain, and was also used by other authors (e.g. Guilhoto, 2004; Xianhui, Yingheng, 2010; Moreira et al., 2016).

However, when used in international benchmarking, it becomes quite problematic. This is especially true for the extraction of sectors comprising the $3^{\text {rd }}$ aggregate (agriculture-based industries). The method proposed above considers the total value of all sectors contained in the aggregate although these sectors may differ between the countries. Therefore, if the assessment takes into account all major sectors (the same in each country), it may result in revaluations. Conversely, if different sectors are identified in each country, this could result in understatements in relation to countries with a larger number of sectors (if a sector is not classed as an agriculture-based industry, it does not necessarily mean it does not require any agricultural produce at all; instead, it only means it requires agricultural produce in small quantities compared to its demand for products of other sectors).

This is not a problem in the case of the classification proposed by Woś (1979) who divided the agribusiness into 3 aggregates: a) supply of goods and services to the agriculture and the food industry; b) agriculture; and c) food industry. That concept, together with its theoretical underpinning, was broadly discussed by Poczta, MrówczyńskaKamińska (2004). It is primarily focused on emphasizing the leading role of the food industry which requires that agribusiness be approached as a subsystem responsible for food production. Furthermore, it assumes that agriculture and the food industry are the major components of agribusiness in each country and that their relationships with other sectors are of key importance. The above is corroborated by findings from a study by Wilkinson and Rocha (2009) which suggest that the food industry has the strongest relationships with agriculture, and its role becomes increasingly important as the population's income grows. That classification became the basis for many other papers 
focusing, for instance, on Poland (Czyżewski, Mrówczyńska-Kamińska, 2011), Germany (Mrówczyńska-Kamińska, Poczta, 2013) or the European Union (Mrówczyńska-Kamińska, 2015).

The momentum for agribusiness production comes primarily from the outside and has the form of industrial products. In turn, productive inputs are one of the basic startup enablers for agribusiness. Hence, the decisive factor behind production growth is the development level of industries which manufacture productive inputs for, and deliver services to, agriculture and the food industry. Each time, production growth in agribusiness results in the emergence of interrelations. On the one hand, agribusiness delivers an increasingly greater volume of raw materials whereas on the other, it demands increasingly more industrial productive inputs and all kinds of services. The analysis of the structure of productive inputs and services delivered for direct use in food production could be an indicator of the development level of agribusiness in the country concerned. In international benchmarking, particular attention should be given to some observable trends. For instance, according to Mrówczyńska-Kamińska (2015), a higher development level of agribusiness is characteristic in that a greater share of material inputs is delivered to the food industry than to agriculture.

Therefore, the purpose of this analysis was to assess the prevailing relationships in the supply structure of the agribusiness sector in European Union countries over the years. The study mainly focuses on observing certain trends that emerged between 2000 and 2014. It is due to the availability of relevant data in these years. Compared to the existing literature, this analysis extends the knowledge on the relationships in the structure of materials supplied to agribusiness in European Union countries. In addition to agriculture, it takes account of the food industry which is often neglected in research. Moreover, based on longterm observations, it endeavors to capture the prevailing relationships in several countries at a time. Also, this study relies on a database of accounts which are methodologically unified across countries and years.

\section{Materials and methods}

The calculations were based on I/O tables retrieved from the World Input-Output Database (WIOD), Release 2016. The advantage of WIOD is that it publishes methodologically unified tables for all countries for the period 2000-2014. Moreover, particular focus is placed on data quality, so that the figures provide the best possible reflection of official national statistics. The study covered 25 European Union members as at November 1, 2019. Cyprus, Malta and Luxembourg were excluded from the analysis due to their small landmass which has a strong impact on agricultural supply figures. In WIOD Release 2016, data for 56 sectors was classified as per the International Standard Industrial Classification of All Economic Activities, Revision 4 (ISIC Rev. 4). The tables were prepared in accordance with the 2008 version of the System of National Accounts (SNA). Detailed information on the structure of tables can be found in publications by Dietzenbacher et al. (2013), Timmer et al. (2015) and Timmer et al. (2016).

The study addressed the changes in the supply structures of agriculture and food industries, the two major components of agribusiness as defined by Woś (1979). The study was of a dynamic nature. Although the study period was 2000-2014, this paper only presents the figures for the first and the last year, i.e. 2000 and 2014, because the trends 
were observed to be constant throughout that period and it is difficult to legibly present such a large number of observations for whole period. As provided for in ISIC Rev. 4, agriculture is defined as sector A01: Crop and animal production, hunting and related service activities. In turn, the food industry are sectors C10-C12: Manufacture of food products, beverages and tobacco products. For the sake of a greater transparency of the inference process, other sectors of the economy were also aggregated in order to carry out the analysis of supply. A list of the sectors extracted together with the corresponding ISIC Rev. 4 codes is shown in Table 1.

Table 1. Division of the sectors analyzed together with the corresponding ISIC Revision 4 codes.

\begin{tabular}{|c|c|}
\hline Aggregated sectors & ISIC Rev. 4 codes \\
\hline Agriculture & $\mathrm{A} 01$ \\
\hline Food industry & $\mathrm{C} 10-\mathrm{C} 12$ \\
\hline Fuel and energy industry & $\mathrm{B} ; \mathrm{C} 19 ; \mathrm{D} 35$ \\
\hline Metallurgical industry & $\mathrm{C} 24 ; \mathrm{C} 25$ \\
\hline Engineering goods industry & $\mathrm{C} 26 ; \mathrm{C} 27 ; \mathrm{C} 28$ \\
\hline Transport equipment & $\mathrm{C} 29 ; \mathrm{C} 30$ \\
\hline Chemical industry & $\mathrm{C} 20$ \\
\hline Construction materials industry & $\mathrm{C} 16 ; \mathrm{C} 23$ \\
\hline Other industries & C13-C15; C17; C18; C21; C22; C31_C32 \\
\hline Construction & $\mathrm{F}$ \\
\hline Services & $\begin{array}{l}\text { C33; E36; E37-E39; G45; G46; G47; H49; H50; H51; H52; H53; I; } \\
\text { J58; J59_J60; J61; J62_J63; K64; K65; K66; L68; M69_M70; } \\
\text { M71; M72; M73; M74_M75; N; O84; P85; Q; R_S }\end{array}$ \\
\hline Other sectors & A02; A03; T; U \\
\hline
\end{tabular}

Source: the classification was based on the authors' own concept underpinned by ISIC Rev. 4 .

\section{Supply of materials to agriculture}

The volume of goods and services supplied to agriculture largely depends on the contribution and importance of agriculture to the economy. Hence, many relationships in that field are correlated with economic growth, a pattern which is corroborated by this study, too. Findings regarding the value and structure of materials supplied to agriculture are shown in Table 2. The countries with the highest value of materials supplied are (in descending order): France, Germany, Italy, Spain, UK, the Netherlands and Poland. These are also the countries with the highest value of agricultural output across the European Union, which comes as no surprise. Similarly, the lowest values of goods and services delivered to agriculture were observed in countries with a lower value of agricultural output.

Self-supply of materials (i.e. materials delivered from agriculture to itself), goods supplied from the food industry and services are the prevailing inputs in most countries. Inputs from the food industry have a small share in all goods and services supplied to agriculture only in countries where the food industry is poorly developed, such as Latvia or Croatia. The general economic dynamism suggests that as the economy grows, the share of agriculture in the supply structure declines while that of other sectors increases. As 
mentioned earlier, materials supplied from the food industry and services become of greater importance.

Table 2. Supply of materials to agriculture in European Union countries in 2000 and 2014 (\%).

\begin{tabular}{|c|c|c|c|c|c|c|c|c|c|c|c|c|c|c|}
\hline Country & Year & USD mln & $\mathrm{CI}$ & EG & $\mathrm{CM}$ & MI & FE & TE & FI & OI & $\mathrm{CO}$ & SE & $\mathrm{AG}$ & OS \\
\hline \multirow{2}{*}{ AUT } & 2000 & 2700 & 6,8 & 2,8 & 1,4 & 1,4 & 6,7 & 0,1 & 16,2 & 3,0 & 2,0 & 21,7 & 37,6 & 0,3 \\
\hline & 2014 & 5402 & 6,0 & 2,2 & 1,4 & 1,9 & 8,9 & 0,2 & 16,4 & 2,3 & 1,9 & 23,6 & 34,8 & 0,2 \\
\hline \multirow{2}{*}{ BEL } & 2000 & 3536 & 12,8 & 1,1 & 0,1 & 0,2 & 9,0 & 0,1 & 27,8 & 2,4 & 0,2 & 38,3 & 8,0 & 0,0 \\
\hline & 2014 & 7769 & 4,6 & 1,0 & 0,6 & 0,5 & 8,9 & 0,2 & 31,3 & 1,3 & 2,2 & 36,7 & 12,7 & 0,0 \\
\hline \multirow{2}{*}{ BGR } & 2000 & 1496 & 5,1 & 0,4 & 0,7 & 1,1 & 5,3 & 0,0 & 3,3 & 1,6 & 1,4 & 26,9 & 53,4 & 0,7 \\
\hline & 2014 & 3275 & 8,6 & 0,6 & 0,8 & 1,7 & 8,5 & 0,1 & 5,1 & 2,1 & 2,3 & 34,8 & 34,0 & 1,3 \\
\hline \multirow{2}{*}{ HRV } & 2000 & 1077 & 11,0 & 1,5 & 0,7 & 1,1 & 4,0 & 0,5 & 2,8 & 0,7 & 0,6 & 72,3 & 4,9 & 0,0 \\
\hline & 2014 & 1840 & 13,1 & 0,8 & 0,4 & 0,9 & 5,7 & 0,2 & 3,3 & 0,6 & 0,3 & 69,2 & 5,4 & 0,0 \\
\hline \multirow{2}{*}{ CZE } & 2000 & 1948 & 10,9 & 2,8 & 0,6 & 1,0 & 6,0 & 0,9 & 36,3 & 1,9 & 0,7 & 24,2 & 14,3 & 0,3 \\
\hline & 2014 & 5807 & 9,1 & 2,7 & 0,4 & 0,7 & 7,6 & 1,0 & 27,3 & 1,8 & 1,1 & 31,8 & 15,8 & 0,6 \\
\hline \multirow{2}{*}{ DNK } & 2000 & 4143 & 4,7 & 1,3 & 0,2 & 0,9 & 5,7 & 0,2 & 24,5 & 1,6 & 4,7 & 31,5 & 23,4 & 1,4 \\
\hline & 2014 & 8887 & 3,9 & 1,3 & 0,3 & 1,1 & 6,6 & 0,2 & 25,7 & 2,0 & 4,1 & 34,0 & 19,5 & 1,3 \\
\hline \multirow{2}{*}{ EST } & 2000 & 195 & 7,4 & 3,2 & 0,7 & 1,4 & 10,8 & 0,5 & 13,1 & 1,8 & 1,8 & 27,4 & 31,9 & 0,1 \\
\hline & 2014 & 703 & 8,3 & 2,9 & 0,5 & 1,3 & 14,1 & 0,4 & 11,3 & 1,6 & 1,9 & 27,6 & 30,0 & 0,1 \\
\hline \multirow{2}{*}{ FIN } & 2000 & 2276 & 11,5 & 3,6 & 0,6 & 2,0 & 5,9 & 0,3 & 18,0 & 2,2 & 1,4 & 25,3 & 29,1 & 0,1 \\
\hline & 2014 & 4269 & 11,6 & 3,5 & 0,3 & 1,2 & 8,2 & 0,2 & 18,8 & 0,9 & 3,7 & 32,5 & 18,8 & 0,3 \\
\hline \multirow[b]{2}{*}{ FRA } & 2000 & 33491 & 12,0 & 2,5 & 1,5 & 0,9 & 4,1 & 0,4 & 16,4 & 3,5 & 0,4 & 22,3 & 35,8 & 0,2 \\
\hline & 2014 & 64199 & 12,1 & 0,4 & 1,8 & 1,0 & 7,1 & 0,4 & 15,2 & 3,5 & 0,8 & 28,8 & 29,0 & 0,0 \\
\hline \multirow{2}{*}{ DEU } & 2000 & 18543 & 9,9 & 3,3 & 2,2 & 1,7 & 7,0 & 1,3 & 16,6 & 2,5 & 1,6 & 45,5 & 8,0 & 0,3 \\
\hline & 2014 & 40067 & 7,0 & 3,8 & 1,4 & 1,5 & 8,7 & 1,2 & 11,7 & 2,0 & 2,6 & 50,6 & 9,2 & 0,2 \\
\hline \multirow{2}{*}{ SVK } & 2000 & 1078 & 10,1 & 2,0 & 0,9 & 1,3 & 12,0 & 0,5 & 5,6 & 3,0 & 2,0 & 23,5 & 38,5 & 0,5 \\
\hline & 2014 & 2540 & 15,0 & 2,8 & 1,4 & 0,8 & 9,7 & 1,0 & 5,9 & 2,5 & 1,4 & 24,7 & 34,5 & 0,3 \\
\hline \multirow{2}{*}{ SVN } & 2000 & 508 & 9,3 & 2,7 & 0,7 & 1,5 & 6,2 & 0,3 & 16,4 & 2,7 & 2,3 & 21,4 & 36,4 & 0,1 \\
\hline & 2014 & 876 & 9,0 & 2,6 & 0,5 & 1,4 & 6,7 & 0,3 & 12,9 & 2,4 & 2,5 & 26,7 & 35,0 & 0,1 \\
\hline \multirow{2}{*}{ GBR } & 2000 & 12945 & 5,4 & 1,6 & 1,3 & 2,5 & 5,8 & 0,9 & 12,2 & 7,1 & 3,4 & 41,5 & 18,4 & 0,0 \\
\hline & 2014 & 24768 & 4,8 & 1,5 & 1,2 & 2,0 & 9,8 & 0,9 & 20,4 & 6,5 & 4,3 & 28,3 & 20,4 & 0,0 \\
\hline \multirow{2}{*}{ GRC } & 2000 & 4173 & 7,0 & 1,4 & 0,1 & 0,2 & 10,5 & 0,9 & 2,4 & 1,8 & 0,5 & 26,4 & 48,8 & 0,0 \\
\hline & 2014 & 7237 & 6,7 & 1,2 & 0,1 & 0,4 & 13,2 & 0,5 & 2,8 & 1,3 & 0,3 & 29,8 & 43,7 & 0,0 \\
\hline \multirow{2}{*}{ HUN } & 2000 & 3352 & 9,9 & 3,5 & 0,8 & 0,9 & 5,9 & 0,7 & 14,8 & 2,8 & 0,3 & 17,0 & 43,1 & 0,3 \\
\hline & 2014 & 6865 & 9,8 & 2,1 & 0,5 & 0,5 & 7,6 & 0,4 & 15,3 & 2,1 & 0,2 & 18,6 & 42,9 & 0,1 \\
\hline \multirow{2}{*}{ IRL } & 2000 & 3125 & 5,8 & 1,3 & 0,3 & 2,2 & 2,3 & 0,2 & 6,9 & 7,0 & 1,3 & 31,9 & 40,9 & 0,0 \\
\hline & 2014 & 7858 & 1,4 & 2,0 & 1,0 & 0,9 & 6,7 & 1,0 & 3,2 & 12,2 & 1,3 & 60,9 & 8,1 & 1,2 \\
\hline & 2000 & 14610 & 8,8 & 1,6 & 1,6 & 1,4 & 7,8 & 0,3 & 15,3 & 3,4 & 1,5 & 35,7 & 22,5 & 0,0 \\
\hline I1A & 2014 & 31066 & 7,7 & 1,5 & 1,5 & 1,3 & 10,9 & 0,2 & 18,7 & 3,3 & 2,5 & 25,3 & 27,2 & 0,0 \\
\hline & 2000 & 571 & 11,8 & 2,0 & 0,5 & 0,2 & 12,7 & 0,1 & 0,5 & 3,2 & 0,1 & 18,9 & 48,3 & 1,6 \\
\hline LVA & 2014 & 2068 & 14,8 & 2,0 & 0,4 & 0,3 & 16,6 & 0,1 & 0,3 & 3,5 & 0,2 & 22,2 & 38,0 & 1,6 \\
\hline & 2000 & 273 & 9,3 & 4,7 & 0,4 & 0,5 & 11,6 & 0,7 & 13,9 & 3,7 & 2,1 & 42,5 & 10,3 & 0,3 \\
\hline LIU & 2014 & 1266 & 20,2 & 3,3 & 0,7 & 0,6 & 15,6 & 0,6 & 10,2 & 3,5 & 1,4 & 36,6 & 6,9 & 0,5 \\
\hline & 2000 & 10115 & 3,5 & 2,3 & 0,5 & 0,5 & 5,6 & 0,3 & 16,2 & 1,7 & 0,7 & 42,9 & 25,7 & 0,2 \\
\hline NLD & 2014 & 23512 & 2,3 & 2,3 & 0,5 & 0,5 & 4,2 & 0,4 & 29,1 & 1,9 & 1,3 & 24,3 & 33,0 & 0,1 \\
\hline POI & 2000 & 8483 & 8,3 & 2,2 & 1,2 & 1,6 & 9,1 & 0,4 & 13,9 & 1,1 & 0,6 & 31,2 & 30,2 & 0,2 \\
\hline POL & 2014 & 19342 & 9,6 & 2,1 & 0,9 & 1,7 & 10,0 & 0,4 & 19,7 & 1,0 & 0,7 & 22,1 & 31,7 & 0,2 \\
\hline & 2000 & 2168 & 7,6 & 0,3 & 2,6 & 0,8 & 6,0 & 0,1 & 30,0 & 2,4 & 2,4 & 19,5 & 28,4 & 0,1 \\
\hline PRT & 2014 & 4656 & 7,5 & 0,3 & 2,6 & 0,7 & 8,7 & 0,1 & 29,7 & 2,0 & 2,1 & 21,2 & 25,0 & 0,1 \\
\hline & 2000 & 3561 & 5,4 & 0,6 & 0,4 & 0,9 & 11,1 & 0,3 & 5,2 & 1,4 & 0,6 & 15,3 & 58,7 & 0,1 \\
\hline ROU & 2014 & 9557 & 5,5 & 0,5 & 0,5 & 1,1 & 8,0 & 0,3 & 4,2 & 1,5 & 1,3 & 36,7 & 40,3 & 0,3 \\
\hline & 2000 & 12031 & 6,2 & 2,6 & 1,5 & 4,4 & 4,4 & 0,7 & 30,3 & 4,5 & 0,8 & 28,0 & 15,9 & 0,6 \\
\hline ESP & 2014 & 25744 & 3,8 & 1,3 & 0,4 & 1,5 & 3,6 & 0,3 & 49,4 & 4,5 & 0,4 & 25,1 & 9,4 & 0,2 \\
\hline SWF & 2000 & 2552 & 4,0 & 3,1 & 1,4 & 1,1 & 7,9 & 1,4 & 21,8 & 4,9 & 2,7 & 27,2 & 24,4 & 0,1 \\
\hline & 2014 & 5638 & 5,1 & 3,0 & 1,1 & 0,8 & 10,5 & 1,1 & 19,5 & 1,0 & 3,7 & 31,4 & 22,5 & 0,2 \\
\hline
\end{tabular}

CI: Chemical industry, EG: Engineering goods industry, CM: Construction materials industry, MI: Metallurgical industry, FE: Fuel and energy industry, TE: Transport equipment, FI: Food industry, OI: Other industries, CO: Construction, SE: Services, AG: Agriculture, OS: Other sectors.

Source: Own calculations based on WIOD Release 2016. 
The above is related to the first of the relationships observed: the share of self-supply in agriculture of EU countries is usually inversely proportional to the share of services delivered to agriculture. Generally, an increase in the share of self-supply in agriculture is accompanied by a decline in the share of services delivered (and vice versa). A broader use of services in agriculture may be indicative of the adoption of a specific production model. Often, countries which report a high value of materials supplied also use a series of stateof-the-art service solutions. German farms are a good example as they broadly use the machinery sharing model which contributes to reducing the initial expenditure and operating costs. It also enables a more efficient use of available capital and labor resources. In Germany, as a result of complying with the principles of rationality, informal neighborhood aid schemes lost their importance to machinery companies and professional machinery service providers (Kołodziejczak, Poczta, 2014). Also, consultancy, accounting, technical research and analyses, advertising and other business services play a dominant role.

Another observation regarding the supply structure is that the share of the chemical industry has changed. In EU countries at higher development levels, the share of the chemical industry in the mix of goods supplied to agriculture either declined or remained at a similar level. Conversely, it grew (or remained at a similar level) in less developed countries over the study period. High values of goods supplied from the chemical industry are mainly due to the considerable use of fertilizers and plant protection products, which could be a factor that puts an ever greater pressure on the environment (Bajan, Mrówczyńska-Kamińska, 2018). More developed countries are more successful in reducing the environmental impacts of agriculture. In turn, poorer countries try to intensify production in an effort to improve their competitiveness, as confirmed by findings presented in this paper. An intensive use of land is among the key factors which contributed to surpluses in the production of agricultural raw materials and, as a consequences, to surpluses in food production. In early 2000s, a policy designed to reduce the intensity of agricultural production started to play an increasingly important role in the European Union. However, from the perspective of economic development around the world (and, first of all, considering the rapid population growth), it is assumed that the volume of chemical industry products supplied to agriculture should grow, at least in the initial stage of development. Note however that increasing the fertilization rates alone will not be an effective way to increase yields if not correlated with proper seed management (Wicki, 2010).

The third pattern observed is that most EU countries experience an increase in the share of goods supplied from the fuel and energy sector to agriculture. This suggests that the European Union's agricultural sector generally moves towards a more industrialized model. On the one hand, a relatively larger amount of fuel is used which reflects a greater use of machinery and equipment. On the other hand, more and more energy is consumed in the food production chain; this aspect has an adverse effect on sustainable development. However, if all machinery and equipment involved in the production of agricultural raw materials is renewed over time, the energy intensity of production should decrease. This is confirmed by the situation observed in some highly developed countries which underwent such modernization processes (Mrówczyńska-Kamińska, 2015). 


\section{Supply of materials to the food industry}

When it comes to the supply of materials to the food industry, relevant data corroborates the previous observation that the value of goods supplied is higher than in agriculture. This is particularly noticeable in highly developed countries (Table 3 ). If the total of materials supplied to agriculture and the food industry were considered as the overall supply of goods and services to the agribusiness of the European Union, the share of goods and services supplied to the industry would be $76 \%$ in 2000 and $77 \%$ in 2014 . Similar ratios were observed throughout the study period (2000-2014). This is indicative of a high development of agribusiness in the European Union because the characteristic feature of poorly developed countries is that goods and services supplied to agriculture have a greater share than those supplied to the food industry. Only in 2000 in Bulgaria, the value of materials supplied to agriculture exceed the value of inputs supplied to the food industry. However, in 2014, the value of inputs supplied to the food industry was already over $57 \%$ of the total value of inputs supplied to agribusiness, indicating that this industry follows an upward trend.

The first general observable relationship is the high share of three sectors (agriculture, services and self-supply) in the supply structure of the food industry in European Union countries. The agricultural sector traditionally plays a dominant role in this structure. In most countries, the share of goods supplied from agriculture varies in the range of 35 to $30.0 \%$ of all inputs supplied to the food industry. This suggests and confirms that the food industry is the main recipient of agricultural raw materials. However, that share can be observed to follow a slight downward trend. In turn, when it comes to internal trade within the food industry at EU level, only Greece and Croatia reported a share below $10 \%$ in each year covered by this study. The level of service use can be considered to reflect the state of the art in food processing. However, this largely depends on what kind of services are delivered. When it comes to services for the European Union's food industry, those related to trade, transport, storage and financial and legal support dominate. Hence, the services largely pertain to distribution activities which seems natural in the context of strong competition and cooperation with sales networks.

The second relationship observed, i.e. the relatively large share of 'other industries' in the amount of materials supplied to the food industry, is also related to distribution. This category includes the values of inputs related to packaging production. Plastic and paper packaging are of particular importance to the food industry. It needs to be emphasized that the patterns related to food industry inputs, as presented in this paper, are relatively constant over time. While the shares of particular sectors fluctuate slightly, agriculture, food industry and services combined together make up a similar percentage of the value of products delivered. Note also that the changes in the structure of materials supply to the food industry go hand in hand with an increase in the value of the materials. This reflects the development processes taking place in the food industry.

Changes brought by socioeconomic development result, on the one hand, in the need for adaptive measures and, on the other, in the need to actively set the development targets. In addition to agriculture, the food industry plays a major role in building food security and stability. It is quite frequently mentioned that production innovations are required in order for the food industry to establish a sustainable competitive edge. Information can flow to the food industry thanks to a greater level of its interconnection with its entire environment. This is reflected in the observable increase in the value of materials supplied. 
Table 3. Supply of materials to the food industry in European Union countries in 2000 and 2014 (\%)

\begin{tabular}{|c|c|c|c|c|c|c|c|c|c|c|c|c|c|c|}
\hline Country & Year & USD mln & $\mathrm{CI}$ & EG & $\mathrm{CM}$ & MI & $\mathrm{FE}$ & $\mathrm{TE}$ & FI & OI & $\mathrm{CO}$ & SE & $\mathrm{AG}$ & OS \\
\hline \multirow{2}{*}{ AUT } & 2000 & 7283 & 2,8 & 1,1 & 1,2 & 1,7 & 2,5 & 0,1 & 19,8 & 7,7 & 1,2 & 28,5 & 33,4 & 0,1 \\
\hline & 2014 & 19832 & 2,7 & 0,8 & 0,9 & 2,4 & 2,8 & 0,1 & 21,9 & 6,0 & 1,6 & 32,5 & 28,0 & 0,2 \\
\hline \multirow{2}{*}{ BEL } & 2000 & 16473 & 2,1 & 1,5 & 0,9 & 1,5 & 2,4 & 0,2 & 21,8 & 7,6 & 0,6 & 40,0 & 21,0 & 0,3 \\
\hline & 2014 & 40644 & 2,3 & 0,5 & 0,9 & 1,1 & 3,3 & 0,1 & 29,6 & 5,8 & 1,0 & 30,4 & 24,8 & 0,3 \\
\hline \multirow{2}{*}{ BGR } & 2000 & 1266 & 1,4 & 0,5 & 0,7 & 0,9 & 4,2 & 0,1 & 13,3 & 2,4 & 1,1 & 35,9 & 39,1 & 0,5 \\
\hline & 2014 & 4391 & 1,8 & 0,6 & 0,7 & 0,9 & 5,2 & 0,1 & 22,0 & 3,1 & 1,5 & 40,5 & 23,1 & 0,7 \\
\hline \multirow{2}{*}{ HRV } & 2000 & 1962 & 2,7 & 1,2 & 1,0 & 1,8 & 5,5 & 0,2 & 3,0 & 7,8 & 0,7 & 33,6 & 42,0 & 0,5 \\
\hline & 2014 & 4365 & 2,8 & 1,2 & 0,9 & 1,7 & 8,5 & 0,2 & 2,5 & 7,8 & 1,4 & 42,7 & 29,8 & 0,4 \\
\hline \multirow{2}{*}{ CZE } & 2000 & 5413 & 1,4 & 0,7 & 1,1 & 0,7 & 2,8 & 0,2 & 32,8 & 3,3 & 0,3 & 25,5 & 30,9 & 0,4 \\
\hline & 2014 & 12570 & 1,1 & 0,8 & 0,7 & 0,8 & 3,4 & 0,2 & 23,1 & 3,7 & 0,5 & 29,8 & 34,6 & 1,4 \\
\hline \multirow{2}{*}{ DNK } & 2000 & 10455 & 1,6 & 1,2 & 0,3 & 1,7 & 2,0 & 0,1 & 28,1 & 4,2 & 0,9 & 20,1 & 35,4 & 4,5 \\
\hline & 2014 & 20454 & 1,5 & 0,8 & 0,5 & 1,2 & 2,2 & 0,1 & 33,4 & 4,0 & 0,8 & 23,3 & 29,3 & 2,7 \\
\hline \multirow{2}{*}{ EST } & 2000 & 476 & 2,1 & 1,2 & 1,2 & 2,1 & 3,3 & 0,2 & 19,4 & 6,6 & 0,3 & 31,0 & 29,9 & 2,8 \\
\hline & 2014 & 1697 & 2,7 & 1,2 & 1,0 & 2,3 & 3,8 & 0,2 & 22,0 & 5,5 & 0,4 & 29,8 & 27,6 & 3,4 \\
\hline \multirow{2}{*}{ FIN } & 2000 & 5896 & 2,4 & 3,0 & 1,1 & 1,3 & 1,7 & 0,2 & 22,8 & 5,7 & 0,4 & 26,3 & 34,8 & 0,3 \\
\hline & 2014 & 11693 & 2,3 & 1,4 & 0,3 & 1,3 & 2,7 & 0,2 & 27,1 & 5,6 & 0,8 & 27,6 & 29,8 & 0,9 \\
\hline \multirow[b]{2}{*}{ FRA } & 2000 & 77657 & 1,9 & 1,0 & 1,0 & 1,1 & 2,5 & 0,1 & 21,6 & 4,3 & 0,2 & 30,4 & 34,5 & 1,4 \\
\hline & 2014 & 147215 & 1,2 & 0,9 & 0,9 & 1,2 & 3,3 & 0,2 & 21,3 & 3,8 & 0,2 & 33,7 & 32,3 & 1,2 \\
\hline \multirow{2}{*}{ DEU } & 2000 & 85762 & 1,3 & 1,5 & 0,9 & 1,0 & 3,0 & 0,2 & 19,3 & 5,2 & 0,9 & 40,0 & 26,4 & 0,2 \\
\hline & 2014 & 185219 & 1,3 & 1,1 & 0,7 & 0,9 & 3,1 & 0,2 & 20,5 & 4,5 & 1,0 & 39,4 & 27,0 & 0,3 \\
\hline \multirow{2}{*}{ SVK } & 2000 & 1549 & 0,9 & 0,6 & 1,3 & 1,2 & 3,8 & 0,1 & 19,8 & 7,3 & 0,4 & 30,1 & 34,4 & 0,2 \\
\hline & 2014 & 3677 & 0,8 & 0,8 & 1,9 & 1,3 & 4,7 & 0,5 & 8,9 & 9,5 & 0,7 & 34,7 & 35,8 & 0,3 \\
\hline \multirow{2}{*}{ SVN } & 2000 & 1097 & 1,5 & 2,7 & 1,4 & 3,3 & 3,2 & 0,6 & 12,0 & 7,3 & 1,0 & 41,8 & 25,0 & 0,1 \\
\hline & 2014 & 1731 & 1,5 & 2,0 & 1,2 & 2,8 & 3,3 & 0,4 & 15,2 & 6,6 & 0,9 & 44,0 & 22,0 & 0,2 \\
\hline \multirow{2}{*}{ GBR } & 2000 & 57278 & 0,8 & 1,8 & 1,3 & 2,5 & 4,2 & 0,5 & 19,2 & 9,9 & 0,5 & 40,3 & 18,0 & 1,0 \\
\hline & 2014 & 102379 & 1,0 & 1,8 & 1,2 & 2,5 & 5,6 & 0,5 & 31,9 & 8,7 & 0,6 & 25,8 & 19,3 & 1,1 \\
\hline \multirow{2}{*}{ GRC } & 2000 & 8318 & 1,0 & 1,2 & 0,4 & 1,2 & 2,2 & 0,2 & 3,4 & 3,0 & 0,6 & 50,1 & 36,8 & 0,1 \\
\hline & 2014 & 14377 & 1,3 & 1,6 & 0,5 & 2,2 & 3,7 & 0,2 & 4,9 & 2,5 & 0,3 & 55,4 & 27,4 & 0,1 \\
\hline \multirow{2}{*}{ HUN } & 2000 & 4850 & 3,4 & 2,3 & 1,1 & 2,6 & 3,4 & 0,4 & 17,0 & 6,9 & 0,3 & 20,9 & 41,4 & 0,2 \\
\hline & 2014 & 10480 & 2,4 & 1,9 & 0,8 & 1,6 & 4,0 & 0,3 & 18,9 & 5,9 & 0,2 & 23,6 & 40,3 & 0,1 \\
\hline \multirow{2}{*}{ IRL } & 2000 & 7741 & 0,9 & 0,7 & 0,6 & 0,8 & 1,6 & 0,2 & 4,4 & 3,9 & 0,6 & 49,1 & 36,2 & 1,2 \\
\hline & 2014 & 26375 & 1,6 & 2,0 & 0,5 & 1,0 & 4,1 & 0,5 & 17,5 & 7,0 & 0,9 & 62,1 & 2,4 & 0,4 \\
\hline JTA & 2000 & 69435 & 1,0 & 0,8 & 1,2 & 0,5 & 3,0 & 0,3 & 22,1 & 1,9 & 0,6 & 43,6 & 24,7 & 0,3 \\
\hline $11 \mathrm{~A}$ & 2014 & 133970 & 1,2 & 0,7 & 1,3 & 0,5 & 2,7 & 0,3 & 31,4 & 2,6 & 0,6 & 30,9 & 27,6 & 0,3 \\
\hline & 2000 & 1226 & 0,4 & 0,5 & 1,6 & 2,8 & 4,4 & 0,2 & 30,1 & 6,0 & 0,4 & 25,6 & 23,4 & 4,5 \\
\hline LVA & 2014 & 3657 & 0,7 & 0,5 & 2,1 & 3,2 & 6,7 & 0,2 & 25,1 & 7,3 & 0,7 & 30,6 & 20,9 & 2,0 \\
\hline LTU & 2000 & 686 & 0,2 & 3,2 & 0,7 & 0,7 & 4,1 & 0,2 & 8,7 & 5,8 & 1,0 & 23,4 & 50,8 & 0,9 \\
\hline LIV & 2014 & 1753 & 0,5 & 2,7 & 1,0 & 0,9 & 5,9 & 0,3 & 10,2 & 9,6 & 0,9 & 29,2 & 34,5 & 4,1 \\
\hline NLD & 2000 & 27825 & 0,8 & 2,3 & 0,5 & 1,7 & 0,9 & 0,1 & 22,3 & 4,4 & 0,3 & 37,7 & 28,8 & 0,3 \\
\hline NLD & 2014 & 64450 & 0,6 & 1,2 & 0,6 & 1,6 & 1,0 & 0,2 & 35,8 & 4,1 & 0,2 & 19,7 & 34,4 & 0,5 \\
\hline POI & 2000 & 15044 & 1,2 & 0,6 & 1,0 & 1,3 & 3,3 & 0,3 & 22,1 & 4,1 & 0,5 & 34,5 & 30,1 & 0,9 \\
\hline PUL & 2014 & 57609 & 1,6 & 0,8 & 0,9 & 1,7 & 4,4 & 0,4 & 28,7 & 4,4 & 0,6 & 29,3 & 25,9 & 1,3 \\
\hline & 2000 & 8171 & 1,3 & 0,6 & 2,7 & 1,4 & 2,6 & 0,1 & 19,3 & 7,9 & 0,9 & 27,5 & 35,3 & 0,3 \\
\hline PRT & 2014 & 15738 & 1,4 & 0,5 & 2,5 & 1,6 & 3,7 & 0,1 & 21,5 & 6,6 & 0,7 & 28,6 & 32,4 & 0,4 \\
\hline ROU & 2000 & 4758 & 0,7 & 0,4 & 1,0 & 0,4 & 3,4 & 0,2 & 20,1 & 1,3 & 0,9 & 16,5 & 55,0 & 0,2 \\
\hline KUण & 2014 & 15253 & 0,7 & 0,5 & 0,7 & 0,5 & 3,7 & 0,2 & 13,8 & 1,5 & 1,9 & 35,3 & 40,2 & 1,0 \\
\hline E & 2000 & 44312 & 1,6 & 2,2 & 2,1 & 2,0 & 2,2 & 0,5 & 21,0 & 5,9 & 0,9 & 31,5 & 29,5 & 0,6 \\
\hline & 2014 & 140160 & 1,5 & 1,4 & 1,1 & 1,0 & 3,0 & 0,3 & 39,8 & 4,1 & 0,5 & 23,0 & 23,7 & 0,6 \\
\hline & 2000 & 9271 & 0,8 & 1,3 & 0,9 & 1,2 & 2,0 & 0,9 & 26,4 & 6,7 & 0,4 & 32,1 & 26,7 & 0,5 \\
\hline SWE & 2014 & 16887 & 1,0 & 1,0 & 1,2 & 1,7 & 3,0 & 0,8 & 25,7 & 6,7 & 0,8 & 31,8 & 25,7 & 0,6 \\
\hline
\end{tabular}

CI: Chemical industry, EG: Engineering goods industry, CM: Construction materials industry, MI: Metallurgical industry, FE: Fuel and energy industry, TE: Transport equipment, FI: Food industry, OI: Other industries, CO: Construction, SE: Services, AG: Agriculture, OS: Other sectors.

Source: Own calculations based on WIOD Release 2016. 


\section{Conclusion}

The analysis of materials supply to the agribusiness allowed to detect several general patterns. As regards the supply of materials to agriculture in European Union countries, the following observations were made: (i) EU countries at higher development levels witness a decline in the share of the chemical industry in the mix of goods supplied to agriculture; it is the opposite in less developed countries; (ii) the share of agricultural inputs coming from the fuel and energy industry grows in most EU countries; this suggests that agricultural production moves towards a more industrialized model; (iii) the share of self-supply in the volume of goods and services supplied to agriculture in EU countries is usually inversely proportional to the share of services delivered to agriculture. When it comes to the supply of materials to the food industry in the countries surveyed, the following was found: (i) a relatively high share of 'other industries' in the supply structure, resulting from the fact that huge quantities of paper and plastic packaging are purchased for use in distribution operations; (ii) the shares of agriculture, services and self-supply combined together in the supply structure are high and relatively stable throughout the study period.

This study extends the existing knowledge on inputs supplied to agriculture and the food industry by indicating certain general trends prevailing in European Union countries. The study was based on data retrieved from WIOD, a database which enables dynamic comparisons as it publishes I/O tables for successive years. This is what makes it more suitable than EUROSTAT. As a consequence, the entire period from 2000 to 2014 could be covered by the study. However, the authors focused on trends which are constant over time, which can be regarded as a certain deficiency. To get to know better the relationships found in the processes of materials supply to agribusiness, the analysis should be carried out at country level which, however, was not the purpose of this study.

\section{Acknowledgements}

The publication was co-financed by the "National Science Centre, Poland" as part of the project "Condition and development of agribusiness in European Union countries" registered under No. 2017/27/N/HS4/01534.

\section{References}

Bajan, B., Mrówczyńska-Kamińska, A. (2018). Przepływy międzygałęziowe w sektorze rolno-żywnościowym w Chinach (Input-Output Analysis in the Chinese Agri-Food Sector). Problemy Rolnictwa Światowego, 18(2), 7-19. DOI: 10.22630/PRS.2018.18.2.30

Czyżewski, B., Mrówczyńska-Kamińska, A. (2011). Przepływy międzygałęziowe i podział rent w sektorze rolnożywnościowym w Polsce w latach 1995-2005 (Input-Output Analysis and the Allocation of Rents in the Agri-Food Sector in Poland, 1995-2005). Ekonomista, 2, 203-233.

Davis, J.H., Goldberg, R.A. (1957). A Concept of agribusiness. Boston, Division of Research, Graduate School of Business Administration, Harvard University.

Dietzenbacher, E., Los, B., Stehrer, R., Timmer, M. P., de Vries, G. J. (2013). The Construction of World InputOutput Tables in the WIOD Project. Economic Systems Research, 25, 71-98. DOI: $10.1080 / 09535314.2012 .761180$. 


\section{B. Bajan, A. Mrówczyńska-Kamińska}

Furtuoso, M., Barros, G., Guilhoto, J. (1998). O produto interno bruto do complexo agroindustrial brasileiro (The Gross National Production of the Brazilian Agroindustrial Complex). Revista de Economia e Sociologia Rural, 36(3), 9-31.

Guilhoto, J. (2004). Regional Importance of the Agribusiness in the Brazilian Economy. Paper Presented at the 44th Congress of the European Regional Science Association Porto, Portugal. 25-29 August. DOI: $10.2139 / \mathrm{ssrn} .2425747$.

Kołodziejczak, M., Poczta, W. (2014): Zmiany w poziomie i strukturze korzystania usług w rolnictwie Polski i Niemiec w latach 1998-2012 (Changes in the level and structure of utilisation of services in Polish and German agriculture in 1998-2012). J. Agribus. Rural Dev., 1(31), 69-79.

Moreira, V., Kureski, R., Veiga, C. (2016). Assessment of the economic structure of Brazilian agribusiness. Scientific World Journal, 1-10. DOI: 10.1155/2016/7517806.

Mrówczyńska-Kamińska, A., (2015). Gospodarka żywnościowa w krajach Unii Europejskiej; kierunki rozwoju, przepływy i współzależności (Agri-food economy in the EU countries directions of development, flows and interdependences). Wydawnictwo Uniwersytetu Przyrodniczego, Poznań.

Mrówczyńska-Kamińska, A., Baer-Nawrocka, A. (2016). The Significance of Agribusiness in the National Economy in the EU Countries in: Chmieliński, P., Soliwoda, W. (eds.) Models for competitive and sustainable agriculture and rural development in central-eastern European countries. Institute of Agricultural and Food Economics - National Research Institute, Warsaw.

Mrówczyńska-Kamińska, A., Poczta, W. (2013). Erzeugung und Verteilung der Produkte des Agrarsektors und der Lebensmittelindustrie vor dem Hintergrund ihrer Verbindungen mit der Volkswirtschaft: vergleichende Analyse des Agrar- und Lebensmittelsektors in Polen und Deutschland (Creation and distribution of products of the agriculture and food industries in view of their interdependency with the national economy: A comparative sectoral analysis of the agri-food sectors in Poland and Germany). Berichte uber Landwirtschaft, 91(1), 133-158. DOI: 10.12767/buel.v91i1.11.g51.

Poczta, W., Mrówczyńska-Kamińska, A. (2004). Agrobiznes w Polsce jako subsystem gospodarki narodowej (Agribusiness in Poland as a subsystem of the national economy). Wyd. AR, Poznań.

Schluter, G., Lee, C., Edmondson, W. (1986). Income and Employment Generation in the Food and Fiber System. Agribusiness, 2(2), 143-158. DOI:10.1002/1520-6297(198622)2:2<143::AID-AGR2720020202>3.0.CO;2$\mathrm{H}$

Timmer, M. P., Dietzenbacher, E., Los, B., Stehrer, R., de Vries, G.J. (2015). An Illustrated User Guide to the World Input-Output Database: the Case of Global Automotive Production. Review of International Economics, 23, 575-605. DOI: 10.1111/roie.12178.

Timmer, M. P., Los, B., Stehrer, R., de Vries, G. J. (2016). An Anatomy of the Global Trade Slowdown based on the WIOD 2016 Release. Groningen growth and development centre.

Wicki, L. (2010). Efekty upowszechniania postępu biologicznego w produkcji roślinnej (The effects of the biological progress dissemination in plant production). Rozpr. Nauk. i Monogr. Wyd. SGGW, Warszawa.

Wilkinson, J., Rocha, R. (2009). Agro-Industry Trends, Patterns and Development Impacts; CAB International: London, UK.

Woś, A. (1979). Związki rolnictwa z gospodarką narodową (Relations between agriculture and national economy). PWRiL, Warszawa.

Xianhui, G., Yingheng, Z. (2010). Chinese Agribusiness: Structure, Linkage and Development - A Comparative Analysis Based on Input-Output Model. Proceedings of the 18th International Input-output Conference. Sydney, Australia. 20-25, June.

Yan, B., Fan, J., Zhou, Y. (2011). Study on the Relationship between Economic Growth and Structural Change of Agribusiness. Proceedings of the 19th International Input-Output Conference. Alexandria, Virginia, USA. 13-17 June.

For citation:

Bajan B., Mrówczyńska-Kamińska A. (2020). Supply of Materials to the Agribusiness Sector of European Union Countries. Problems of World Agriculture, 20(1), 15-24;

DOI: $10.22630 /$ PRS.2020.20.1.2 